\title{
Utilization of electronic scraps on making a concrete brick
}

\author{
Yusnimar Sahan ${ }^{1, *}$, Dewi Lusi Jayanti ${ }^{1}$, and Nurul Dwi Anggriana ${ }^{1}$ \\ ${ }^{1}$ Department of Chemical Engineering, Universitas Riau, Pekanbaru, Indonesia
}

\begin{abstract}
Electronic scraps is becoming one of the environment issues globally, including in Indonesia. Innovation in the electronic technologies is growing very rapidly (printer, computers, mobile phones, etc.) and consumers tend to replace électronic goods in a relatively short time. However, the development of electronic tools is not comparable with the invention of its recycling technology, so landfill becomes the first choice to over come the number of electronic scraps that are increasing every year. Most of the electronic scraps are made from $\pm 30-65 \%$ engineering thermoplastics and the rest are metal alloys. In this research, an alternative effort has been made for utilization of thermoplastics as a partial filler replacement for fine sand into commercially valuable products, a concrete brick. As a result, the maximum compressive strength of the concrete brick is $219.968 \mathrm{~kg} / \mathrm{cm}^{2}$ by using thermoplastics $\pm 10 \%$ higher than a concrete brick normally, it does not cause scratches when scratched with nails, also not cause a loud sound when two bricks beaten one with the other and a punch is not too hard.
\end{abstract}

\section{Introduction}

Recently, electronic scraps are becoming one of the causes of environmental problems in almost all countries, including in Indonesia. The invention and technological innovation in the field of electronics is growing very rapidly, and most people tend to replace electronic goods in a relatively short time. However, this is not comparable with the invention of recycled technology of electronic scraps, so the way to overcome the electronic scraps is done in a landfill.

The United Nations University, along with the International Telecommunication Union (ITU) and the International Solid Waste Association (ISWA) estimated that the electronic scraps were generating by the Indonesian population at 1.274 million tonnes or an average of 4.9 kilograms per capita throughout 2016 [1]. The world community generated 44.7 million tonnes or an average of 6.1 kilograms per person by 2016 [2-4]. The amount of electronic scraps is increasing to 52.2 million tonnes in 2021. China became the world's 'champion' of the largest electronic scraps producer, followed by the United States and Indonesia is ranked $9^{\text {th }}$ position.

\footnotetext{
*Corresponding author: yusnisahan@1ecturer.unri.ac.id
} 
Several studies have made efforts to overcome the problem of plastic waste such as plastic bottles, recycled plastic waste polyethylene terephthalate (PET) [5-7]. However, research about engineering thermoplastic utilization of electronic scraps in the infrastructure materials production is not many. In this study, the engineering thermoplastic as a part of electronic scraps is used as filler material on the infrastructure materials production such as a concrete brick.

Some electronic scraps consist of engineering thermoplastic around $30-65 \%$ and the rest are metal alloys $[8,9]$. Thermoplastic is a polymer compound built by many monomers turn into a macromolecule with molecule weight around 500-10,000 [Callister, 2007]. In a polymer or macromolecule built by at least one thousand atoms minimally that are bonding with each other by a covalent bond. Several type bonding in macromolecule such as a linear chain, branch chain, and three dimension system [10]. Type of engineering thermoplastic of electronic scraps namely Acronitrile-Butadiene-Styrene (ABS), Polycarbonate, Polyamide, Polyethylene Terephthalate (PET), Polyvinyl Chloride (PVC), Polypropylene (PP), HighDensity Polyethylene (HDPE), Low-Density Polyethylene (LDPE), and styrofoam. Plastics can be degradation and decomposition in a very long time such as plastic beverage bottles 450 years, foamed plastic buoy 80 years, foamed plastic cups 50 years, plastic film container 20-30 years, plastic bag 10-20 years [11]

Decomposition process of plastics is happening in a long time. Generally, it buried up to tens or even hundreds of years in the soil. This research is very important to be done. This research aim is to find the ways to overcome the problem of electronic scraps, in particular, the engineering thermoplastic part can be treated to a product commercially. Advantages and targets of this research are to participate in supporting regional and national development programs by providing an alternative way out for the community in increasing the added value of electronic scraps. Advantages for the development of science and technology is to provide information in the field of science, especially studies on recovering, recycle and reuse $(3 \mathrm{R})$ on engineering thermoplastics of electronic scraps so that it can be used as a source of fillers on the infrastructure materials production such as a concrete brick.

The making of concrete brick is done by using solidification technique and method of SNI 03-0349-1989 [12]. Solidification is a method for treating solid waste in the form of fine granules into solid products by adding a binder. This technique aims to convert hazardous and toxic solid wastes into non-hazardous and toxic solid products. In this technique, the little solid waste or powder is processed in such a way by the aid of a particular binder into a product having high physical properties of its strength. The increased physical strength is affected in permeability reducing of a product, so the rate of migration of harmful and toxic contaminant particles is becoming limited and these particles in a stable state because it is bound by a binder so it could not penetrate the environment.

\section{Materials and methods}

Materials were applied such as an engineering thermoplastic of printer scraps, portland cement, fine sand, and water. Engineering thermoplastic was separated from the metal parts of printer scraps, and then it was crushed and screened into a small part which has irregular shapes. Cement with the trademark of Semen Padang in $50 \mathrm{~kg}$ pack is used as a Portland cement, while the fine sand is obtained from Kampar and the water is obtained from drilling well that located in the Brickyard "Mutiara Berlian" in Pekanbaru, Indonesia. Functioning water is allowed the chemical reaction of binding and the onset of hardening between the cement with sand and other materials into a thick slurry. 
The tools used in this study are an analytical balance, measuring cup, bucket, sand siever, cement spoon, crusher and screener for arranging particle size of engineering thermoplastic, brick mold with brand "Gita," calculator and computer. To calculate the number of raw materials for concrete brick production, firstly, we have examined the specific gravity of each raw materials to calculate the material composition to produce for concrete bricks. The composition of the raw materials to produce a concrete brick can be seen in Table 1.

Tabel 1. Composition of raw materials for making concrete bricks.

\begin{tabular}{|c|c|c|c|c|}
\hline \multicolumn{3}{|c|}{ Amount of raw material } & \multirow{2}{*}{$\begin{array}{c}\text { Thermoplastic } \\
(\%)\end{array}$} & Concrete brick \\
\cline { 1 - 2 } Cement (kg) & Sand (kg) & Thermoplastic (kg) & 0 & $\mathrm{~B}_{0}$ \\
\hline 2.511 & 8.424 & 0 & 0.914 & $\mathrm{~B}_{1}$ \\
\hline 2.511 & 8.324 & 0.1 & 1.829 & $\mathrm{~B}_{2}$ \\
\hline 2.511 & 8.124 & 0.2 & 2.743 & $\mathrm{~B}_{3}$ \\
\hline 2.511 & 8.024 & 0.3 & 3.657 & $\mathrm{~B}_{4}$ \\
\hline 2.511 & 7.924 & 0.4 & 4.572 & $\mathrm{~B}_{5}$ \\
\hline 2.511 & 7.824 & 0.5 & 5.487 & $\mathrm{~B}_{6}$ \\
\hline 2.511 & 7.724 & 0.6 & 6.401 & $\mathrm{~B}_{7}$ \\
\hline 2.511 & 7.624 & 0.7 & 7.316 & $\mathrm{~B}_{8}$ \\
\hline 2.511 & 7.524 & 0.8 & 8.230 & $\mathrm{~B}_{9}$ \\
\hline 2.511 & 7.424 & 0.9 & 9.145 & $\mathrm{~B}_{10}$ \\
\hline 2.511 & 7.324 & 1.0 & 10.059 & $\mathrm{~B}_{11}$ \\
\hline 2.511 & 7.224 & 1.1 & & \\
\hline
\end{tabular}

Engineering thermoplastic was used granular with irregular shapes. In principle, the sand was sifted first before used and all raw materials to be used for the concrete brick production are weighed according to the data in Table 1 . Then the sand, cement and thermoplastic granules are mixed, gradually adding water to the mixture evenly into a thick slurry and the dough can be printed. Afterward, the thick slurry is inserted into the mold, and the concrete brick is placed with the power of about 7.7 horse Power after this the wet concrete bricks were obtained. Finally, the wet concrete bricks were dried under the sun for 28 days. The dimension of the concrete brick or test specimen to be used in this study is 30 $\mathrm{cm}$ length, $15 \mathrm{~cm}$ width, $9 \mathrm{~cm}$ thick $(30 \times 15 \times 9 \mathrm{~cm})$. The quality of the concrete brick was determined based on the physical, visual observation test on the concrete brick, the determination of dry weight, compressive strength, and water absorption of the dry brick.

The procedure for calculating the weight of the concrete brick is done as follows, and the concrete brick is dried in the open area exposed to the direct sun, then it is weighed. Results of the weight of the concrete brick obtained were compared with the weight of the concrete brick in a different composition. The size of the concrete brick was tested through the visual appearance of the brickwork visually, and measurements of the concrete brick dimensions were measured in length, width, and thickness. 
The ability of a concrete brick to absorb water was measured according to the method of SNI 03-0349-1989 as follows, the sample of dried concrete brick was weighed first, then the sample of the brick input into the container containing the water and the sample was soaked for 24 hours. After 24 hours, the concrete brick sample was weighed to determine the wet weight of the sample. The absorption rate against water is calculated using Eq. 1:

$$
W_{a}=\frac{M_{j}-M_{k}}{M_{k}} \times 100 \%
$$

where $W a$ is water absorption (\%), $M k$ is the dry material weight $(\mathrm{kg})$ dan $M j$ is the saturated material with water or the wet weight of the sample $(\mathrm{kg})$.

The compressive strength test on a concrete brick was done according to SNI 03-03491989 method. The surface of the concrete brick to be tested strongly is cleaned first. Then the brick sample was placed in right in the middle of the positioning style. The sample continues to be loaded if the broken sample is recorded the last digit shown on the press test apparatus. The compressive strength is the ability of the material to withstand the load or mechanical force until the failure (failure) and can be calculated using Eq. 2:

$$
F_{\text {maks }}=\frac{P}{A}
$$

where $F_{\text {maks }}(\mathrm{MPa})$ is compressive strength, $P$ is maximum load $(\mathrm{N})$ or maximum force $(\mathrm{N}), A$ is surface area of speciment test $\left(\mathrm{m}^{2}\right)$.

\section{Results and discussion}

\subsection{Examination of physical appearance}

There are several quality requirements for a concrete brick. Quality requirements are based on SNI 03-0691-1996 [13] namely: the outward visibility of the concrete brick, concrete brick should have a flat surface, no cracks and defects, the corners and ribs are not easily trimmed with the strength of fingers. The result of the examination of physical appearance in the concrete brick product can be seen in Table 2. In Table 2, ten concrete bricks produced with different compositions fulfilling the physical appearance according to standard SNI 03-0349-1989 since almost all of the concrete bricks have a flat surface area, ribs are not cracked and smooth surface. However, the concrete brick containing thermoplastic granules is about $9-10 \%$, the concrete brick has an uneven surface area and less smooth surface. It can be concluded that the particular size of raw materials can be affected to the physical appearing of the concrete brick product. In principle, if on the manufacture of concrete brick used grain size of raw materials are almost as large, then the concrete brick made into solid and surface of the concrete brick field is not cracked [14].

\subsection{Concrete brick size determination}

According to SNI 03-0691-1996 standards [13], the concrete brick must have a minimum nominal thickness of $60 \mathrm{~mm}$ with a tolerance of $\pm 8 \%$. The concrete brick produced in this study is suitable with SNI 03-0691-1996 and provisions of SNI 030348-1989 [14]. There are differences in size in eleven concrete bricks, but the difference is not significant (Table 3 ). This is because the thermoplastic granules used as a filler can be distributed and fill the cavity between the sand causing the concrete brick becomes more solid so that the surface of the concrete brick becomes flat and not cracked. 
Table 2. Differences physical appearance of the concrete brick with standard of SNI 03-0349-1989.

\begin{tabular}{|c|c|c|c|c|c|c|}
\hline \multirow{2}{*}{$\begin{array}{c}\text { Concrete } \\
\text { brick }\end{array}$} & \multicolumn{5}{|c|}{ Field } & \multicolumn{3}{|c|}{ Lateral } \\
\cline { 2 - 7 } & Flattening & Rift & Smoothness & Unity & Sharpness & Strength \\
\hline $\mathrm{B}_{0}$ & Flat & not cracked & Smooth & Elbow & Sharp & Strong \\
\hline $\mathrm{B}_{1}$ & Flat & not cracked & Smooth & Elbow & Sharp & Strong \\
\hline $\mathrm{B}_{2}$ & Flat & not cracked & Smooth & Elbow & Sharp & Strong \\
\hline $\mathrm{B}_{3}$ & Flat & not cracked & Smooth & Elbow & Sharp & Strong \\
\hline $\mathrm{B}_{4}$ & Flat & not cracked & Smooth & Elbow & Sharp & Strong \\
\hline $\mathrm{B}_{5}$ & Flat & not cracked & Smooth & Elbow & Sharp & Strong \\
\hline $\mathrm{B}_{6}$ & Flat & not cracked & Smooth & Elbow & Sharp & Strong \\
\hline $\mathrm{B}_{7}$ & Flat & not cracked & Smooth & Elbow & Sharp & Strong \\
\hline $\mathrm{B}_{8}$ & Flat & not cracked & Smooth & Elbow & Sharp & Strong \\
\hline $\mathrm{B}_{9}$ & Flat & not cracked & Smooth & Elbow & Sharp & Strong \\
\hline $\mathrm{B}_{10}$ & Flat & Cracked & Not smooth & Elbow & Sharp & Strong \\
\hline $\mathrm{B}_{11}$ & Not flat & Cracked & Not smooth & Elbow & Sharp & Strong \\
\hline $\begin{array}{c}\text { SNI 03- } \\
0349- \\
1989\end{array}$ & Flat & not cracked & Smooth & Elbow & Sharp & Strong \\
\hline
\end{tabular}

In Table 3, the dimension of concrete bricks product have not significant differences. The condition is due to the way of making concrete brick manually to obtain concrete brick with a density that is not uniform. Because the density of the pores in the brick will greatly affect the density of the concrete brick composition.

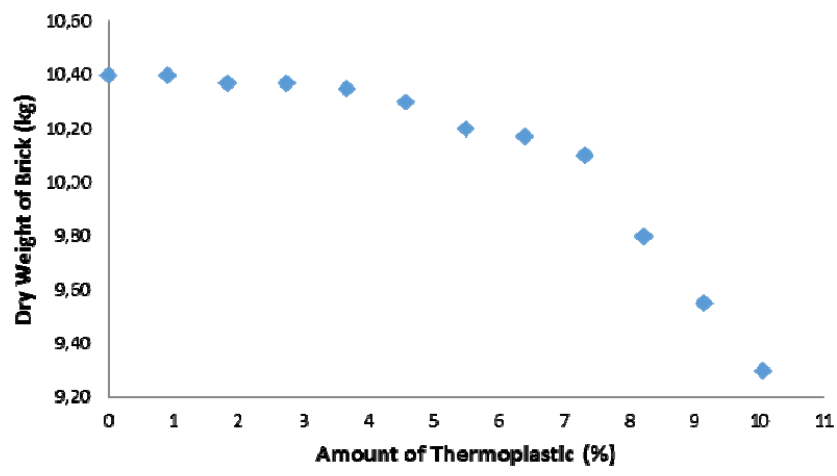

Fig. 1. Amount of thermoplastic used and weigth dried of brick.

Amount variation treatment of engineering thermoplastic is an influence for the dry weight of the concrete bricks (Fig. 1). The more thermoplastic applied to produce concrete 
bricks, the dry weight of the concrete bricks is decreasing. This is because the density of engineering thermoplastic $\left(1.04-1.07 \mathrm{~kg} / \mathrm{m}^{3}\right.$ [17-19] is lower than the density of sand $(2600$ $\mathrm{kg} / \mathrm{m}^{3}$ ) [20].

Table 3. Differences between the measured result of concrete brick dimension and quality standard of SNI 03-0349-1989.

\begin{tabular}{|c|c|c|c|c|c|c|}
\hline \multirow{2}{*}{$\begin{array}{c}\text { Concrete } \\
\text { brick }\end{array}$} & \multicolumn{2}{|c|}{ Length (cm) } & \multicolumn{2}{c|}{ Width (cm) } & \multicolumn{2}{c|}{ Thick (cm) } \\
\cline { 2 - 7 } & Results & $\begin{array}{c}\text { SNI 03- } \\
\mathbf{0 3 4 8 - 1 9 8 9}\end{array}$ & Results & $\begin{array}{c}\text { SNI 03- } \\
\mathbf{0 3 4 8 - 1 9 8 9}\end{array}$ & Results & $\begin{array}{c}\text { SNI 03- } \\
\mathbf{0 3 4 8}-1989\end{array}$ \\
\hline $\mathrm{B}_{0}$ & 30 & 30 & 14.7 & 15 & 8.8 & 9 \\
\hline $\mathrm{B}_{1}$ & 29.5 & 30 & 14.8 & 15 & 8.7 & 9 \\
\hline $\mathrm{B}_{2}$ & 29.6 & 30 & 14.9 & 15 & 8.6 & 9 \\
\hline $\mathrm{B}_{3}$ & 30 & 30 & 14.8 & 15 & 8.8 & 9 \\
\hline $\mathrm{B}_{4}$ & 30 & 30 & 14.9 & 15 & 8.8 & 9 \\
\hline $\mathrm{B}_{5}$ & 29.7 & 30 & 14.7 & 15 & 8.9 & 9 \\
\hline $\mathrm{B}_{6}$ & 29.9 & 30 & 14.8 & 15 & 8.7 & 9 \\
\hline $\mathrm{B}_{7}$ & 29.6 & 30 & 14.7 & 15 & 8.6 & 9 \\
\hline $\mathrm{B}_{8}$ & 29.9 & 30 & 14.8 & 15 & 8.8 & 9 \\
\hline $\mathrm{B}_{9}$ & 29.8 & 30 & 14.9 & 15 & 8.8 & 9 \\
\hline $\mathrm{B}_{10}$ & 29.7 & 30 & 14.7 & 15 & 8.7 & 9 \\
\hline $\mathrm{B}_{11}$ & 29.6 & 30 & 14.8 & 15 & 8.8 & 9 \\
\hline
\end{tabular}

\subsection{Determination water absorpsion of concrete brick}

The results of water absorption by concrete bricks can be seen in Table 4. Overall, the varying amount of thermoplastic treatment is affected to of water absorption by concrete bricks. Water absorption in concrete brick is influenced by several factors, including material type and properties, material size, density level in a concrete structure, and many other things [15]. Abundant water absorption may cause a decrease in strength in the concrete brick. This is due to the higher water absorption by concrete brick, the porosity level in the concrete brick structure will also be higher so that the concrete brick becomes easily cracked and broken. The smaller the percentage of water content absorbed by the concrete brick will be the better the concrete brick because it means the brick has a well mixed density.

Along with the amount of thermoplastic used in concrete brick, the absorption of water increases. However, the water absorption occurring in the concrete still meets the standards set by SNI 15-2094-2000 on the brick [16], the maximum water absorption requirement 20\%. Based on data in Fig. 2 and compared with standard SNI 03-0349-1989 [12], all concrete bricks with different amount of thermoplastic and sand composition have the quality of level I. Concrete brick with quality level I is concrete brick can be used for street construction and footpath. 
Tabel 4. Differences between the average concrete brick absorption of water and the quality standard of SNI 03-0691-1996.

\begin{tabular}{|c|c|c|c|}
\hline \multirow{2}{*}{$\begin{array}{c}\text { Concrete } \\
\text { brick }\end{array}$} & \multicolumn{2}{|c|}{$\begin{array}{c}\text { The average concrete brick } \\
\text { absorption of water (\%) }\end{array}$} & \multirow{2}{*}{ Quality level } \\
\cline { 2 - 3 } & Results & SNI 03-0691-1996 & \\
\hline $\mathrm{B}_{0}$ & 2.40 & 3 & $\mathrm{I}$ \\
\hline $\mathrm{B}_{1}$ & 2.21 & 3 & $\mathrm{I}$ \\
\hline $\mathrm{B}_{2}$ & 2.12 & 3 & $\mathrm{I}$ \\
\hline $\mathrm{B}_{3}$ & 1.64 & 3 & $\mathrm{I}$ \\
\hline $\mathrm{B}_{4}$ & 1.55 & 3 & $\mathrm{I}$ \\
\hline $\mathrm{B}_{5}$ & 1.55 & 3 & $\mathrm{I}$ \\
\hline $\mathrm{B}_{6}$ & 1.47 & 3 & $\mathrm{I}$ \\
\hline $\mathrm{B}_{7}$ & 1.28 & 3 & $\mathrm{I}$ \\
\hline $\mathrm{B}_{8}$ & 1.19 & 3 & $\mathrm{I}$ \\
\hline $\mathrm{B}_{9}$ & 1.02 & 3 & $\mathrm{I}$ \\
\hline $\mathrm{B}_{10}$ & 0.84 & 3 & $\mathrm{I}$ \\
\hline $\mathrm{B}_{11}$ & 0.75 & 3 & $\mathrm{I}$ \\
\hline
\end{tabular}

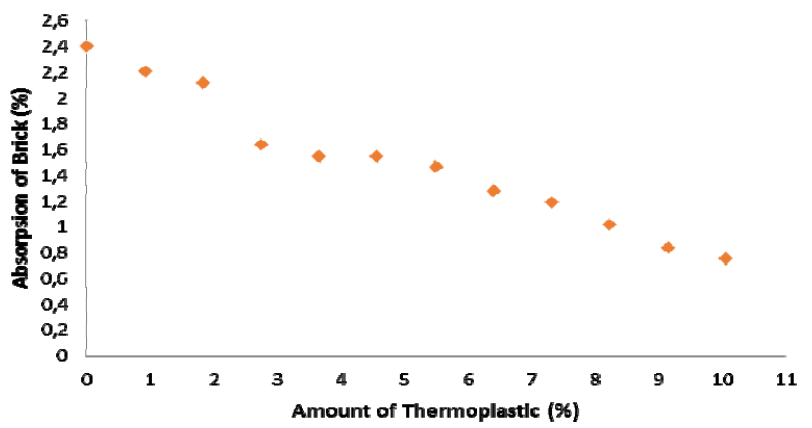

Fig. 2. Amount of thermoplastic used and water absorpsion by concrete bricks.

\subsection{Determination compressive strength of concrete brick}

The result of determining the compressive strength of concrete brick can be seen in Table 5 . Factors affecting to the compressive strength of the concrete brick are the type and quality of raw materials, the method of making concrete brick or paving block, the ratio of the amount of material used and the treatment of concrete brick $[15,16]$. It is predicted that the use of thermoplastic grains as partial replacement of sand can cause the hydration reaction between cement and sand to be disturbed to reduce the compressive strength value of the concrete brick. 
Table 5. Differences between the average compressive strength of concrete brick and the quality standard of concrete brick.

\begin{tabular}{|c|c|c|c|}
\hline \multirow{2}{*}{$\begin{array}{c}\text { Concrete } \\
\text { brick }\end{array}$} & \multicolumn{2}{|c|}{$\begin{array}{c}\text { The average compressive strength } \\
\text { (kg/cm } \mathbf{2}^{2}\end{array}$} & \multirow{2}{*}{ Quality level } \\
\cline { 2 - 3 } & Results & SNI 03-0691-1996 & \\
\hline $\mathrm{B}_{0}$ & 23.369 & 25 & $\mathrm{IV}$ \\
\hline $\mathrm{B}_{1}$ & 136.867 & 100 & $\mathrm{I}$ \\
\hline $\mathrm{B}_{2}$ & 143.853 & 100 & $\mathrm{I}$ \\
\hline $\mathrm{B}_{3}$ & 149.757 & 100 & $\mathrm{I}$ \\
\hline $\mathrm{B}_{4}$ & 157.207 & 100 & $\mathrm{I}$ \\
\hline $\mathrm{B}_{5}$ & 166.008 & 100 & $\mathrm{I}$ \\
\hline $\mathrm{B}_{6}$ & 167.829 & 100 & $\mathrm{I}$ \\
\hline $\mathrm{B}_{7}$ & 169.043 & 100 & $\mathrm{I}$ \\
\hline $\mathrm{B}_{8}$ & 182.239 & 100 & $\mathrm{I}$ \\
\hline $\mathrm{B}_{9}$ & 191.198 & 100 & $\mathrm{I}$ \\
\hline $\mathrm{B}_{10}$ & 216.691 & 100 & $\mathrm{I}$ \\
\hline $\mathrm{B}_{11}$ & 219.968 & 100 & $\mathrm{I}$ \\
\hline
\end{tabular}

The hydration reaction occurs when the cement is added by water. Hydration reactions that produce various chemical compounds. The hydration reaction mechanism of the cement components is as follows [21]:

$$
\begin{gathered}
2 \mathrm{Ca}_{3} \mathrm{OSiO}_{4}+6 \mathrm{H}_{2} \mathrm{O} \rightarrow 3 \mathrm{CaO} \cdot 2 \mathrm{SiO}_{2} \cdot 3 \mathrm{H}_{2} \mathrm{O}+3 \mathrm{Ca}(\mathrm{OH})_{2} \\
2 \mathrm{Ca}_{2} \mathrm{SiO}_{4}+4 \mathrm{H}_{2} \mathrm{O} \rightarrow 3 \mathrm{CaO} \cdot 2 \mathrm{SiO}_{2} \cdot 3 \mathrm{H}_{2} \mathrm{O}+\mathrm{Ca}(\mathrm{OH})_{2} \\
\mathrm{Ca}_{3}\left(\mathrm{AlO}_{3}\right)_{2}+3 \mathrm{CaSO}_{4}+32 \mathrm{H}_{2} \mathrm{O} \rightarrow \mathrm{Ca}_{6}\left(\mathrm{AlO}_{3}\right)_{2}\left(\mathrm{SO}_{4}\right)_{3} .32 \mathrm{H}_{2} \mathrm{O} \\
\left.\mathrm{Ca}_{6}\left(\mathrm{AlO}_{3}\right)_{2}\left(\mathrm{SO}_{4}\right)_{3} .32 \mathrm{H}_{2} \mathrm{O}+\mathrm{Ca}_{3}\left(\mathrm{AlO}_{3}\right)_{2}+4 \mathrm{H}_{2} \mathrm{O} \rightarrow 3 \mathrm{Ca}_{4}\left(\mathrm{AlO}_{3}\right)_{2} \mathrm{SO}_{4}\right) .12 \mathrm{H}_{2} \mathrm{O} \\
2 \mathrm{Ca}_{2} \mathrm{AlFeO}_{5}+\mathrm{CaSO}_{4}+16 \mathrm{H}_{2} \mathrm{O} \rightarrow \mathrm{Ca}_{3}\left(\mathrm{AlO}_{3}\right)_{2}(\mathrm{SO} 4)_{3} \cdot 12 \mathrm{H}_{2} \mathrm{O}+\mathrm{Ca}(\mathrm{OH})_{2}+2 \mathrm{Fe}(\mathrm{OH})_{3}
\end{gathered}
$$

Tricalcium silicate $\left(\mathrm{C}_{3} \mathrm{~S}\right)$ compounds and dicalcium silicate $\left(\mathrm{C}_{2} \mathrm{~S}\right)$ are the most dominant part in giving cement properties, both of which occupy $70-80 \%$ of the cement. $\mathrm{C}_{2} \mathrm{~S}$ compounds have a major effect on cement hardening, especially before reaching the age of 14 days. $\mathrm{C}_{3} \mathrm{~S}$ compounds have an effect on cement hardening after age more than seven days and give final strength. The hydration reactions 1 and 3 are very rapid in a minute order, while the (2), (4) and (5) reactions are slow in week order. Therefore maximum cement hardening can take up to 28 days [21].

Different sized particles of plastic waste that used in concrete brick affect the compressive strength of concrete brick [6]. Thoeneycroft et al. [6] made structural concrete by using three different sized particles of recycled plastic waste $(0.5,2 \& 4 \mathrm{~mm})$, five 
plastic types (PET, HDPP, HDPE, PPF, PPS) and several shapes of plastic as a partial replacement for sand. Eleven concrete mixes tested with plastic as a partial replacement for sand. Results, the use of a graded PET plastic fragments graded as sand matched to the size of the sand particles it replaces, and at a replacement of $10 \%$ by volume, gave the most promising target compressive strength of $54 \mathrm{Mpa}$ to replicate structure concrete, for overall performance. Testing different forms of plastic has demonstrated that the most efficient plastic aggregate used in a concrete mix should have a rough surface, be irregular in shape, and be sufficiently small to not a create a significant failure surface, but also be graded similarly to the sand it replaces.

A varying amount of thermoplastic treatment is influenced to of compressive strength of concrete brick. With the addition of thermoplastic granules on the manufacture of concrete brick, the value of concrete brick compressive strength is increased compared with concrete brick which does not contain thermoplastic (Fig. 3). The concrete brick containing $\pm 10 \%$ thermoplastic granular has the maximum compressive strength compared to other concrete brick. Because of the engineering thermoplastic has physical properties such as malleable, strong and not easy broken, so it can contribute it's special physical properties to the product. The concrete brick containing thermoplastic granules is about $9-10 \%$, it has an uneven surface area and less smooth surface than other concrete bricks (Table 2).

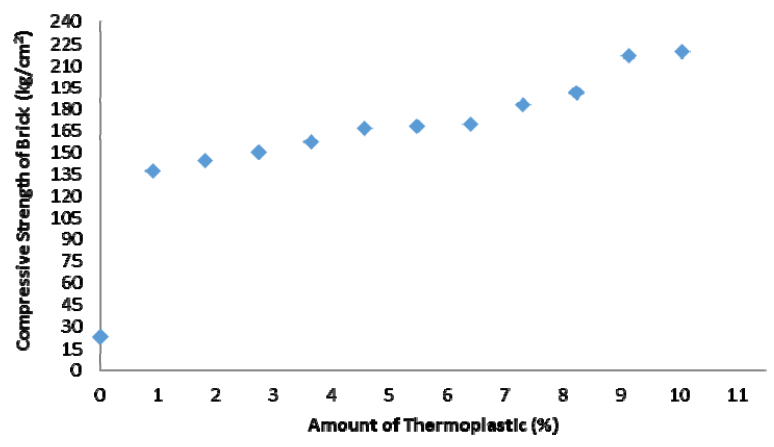

Fig. 3. Amount of thermoplastic used and compressive strength of concrete brick.

Mansour and Ali [7] are examined both structurally and thermally plastic bottles to be utilized as building units, replacing traditional concrete blocks. Test were conducted after filling the bottles with either dry sand, saturated sand or air, or air, bound by cement mortar to produce stable mansory walls of reduced thermal conductivity. The effect of the infill material on the bulk unit weight and the compressive strength of the plastic bottles mansory blocks showed slight effect of the used infill material on the strength. Although the gross strength of these plastic bottles is much less than the traditional blocks, $670 \mathrm{kN} / \mathrm{m}^{2}$ compared to $3670 \mathrm{kN} / \mathrm{m}^{2}$, but calculations showed that the blocks of air filled bottles still can be used as suitable construction units for partition walls or as bearing walls for one roof slab. Thermal wise, air filled bottles showed better thermal insulation than the tradition block construction, which could act as thermal insulation material.

\section{Conclusions}

A varying amount of thermoplastic treatment in making concrete bricks are affected by a product such as it's physical appearance, compressive strength, dry weight, and water absorption by concrete bricks. The compressive strength of concrete brick maximally $219.968 \mathrm{~kg} / \mathrm{cm}^{2}$ for a concrete brick which is treated by thermoplastic $10 \%$ of raw material total weight. The average dry weight of this concrete brick $9.3 \mathrm{~kg}$, water absorption by this 
concrete brick $0.75 \%$. Quality level for all concrete bricks that treated by thermoplastic is level I based on SNI 03-0691-1996 and SNI 030348-1989.

This reasearch is funded by DIPA-LPPM Grant 2018 Universitas Riau. Thanks for the sponsor, Head of LPPM-UNRI, Dean of Engineering Faculty, and students who help this research.

\section{References}

1. United Nation Environment Programme, Sustainable innovation and technology transfer industrial sector studies: recycling from e-waste to resources (Oktoberdruck AG, Berlin, 2009)

2. PTI, 60 cities generate over 15,000 tonnes of plasticwaste per day. Available at https://timesofindia.indiatimes.com/home/environment/pollution/60-cities-generateover-15000-tonnes-of-plastic-waste-per-day/articleshow/47110633.cms (2015)

3. L. Syahban, Ke mana sampah elektronik dibuang. Available at https://x.detik.com/detail/intermeso/20180119/Ke-Mana-Sampah-Elektronikdibuang/index.php (2018)

4. Department of Statistics, Ministry of Trade \& Industry Republic of Singapore, Population Trends 2012 (Singapore Department of Statistics, Singapore, 2012)

5. Y. Amran, TAPAK 1, 2 (2015)

6. J. Thoeneycroft, J. Orr, P. Savoikar, R. Ball, Con. Build. Mat. 161 (2018)

7. A.M.H. Mansour, S.A. Ali, Energy for Sustainable Development 24 (2015)

8. O. Deubzer, E-waste management in Germany (United Nations University Institute for Sustainability and Peace, Germany, 2011)

9. V. Kogan (inventor), U.S. Patent WO2006013568A2. Recovery of precious metals from electronic scrap by hydrometallurgical processing (2006)

10. W.D. Jr. Callister, Materials science and engineering, An introduction (Wiley Publishers, New York, 2006)

11. Plastics International, Material Properties-HDP, Available at https://www.plasticsintl.com/sortable_materials.php (2017)

12. Standar Nasional Indonesia, Bata Beton untuk Pasangan Dinding SNI 03-0349-1989 (Badan Standardisasi Nasional, Jakarta, 1989)

13. Standar Nasional Indonesia, Bata Beton (Paving Block) SNI 03-0691-1996 (Badan Standardisasi Nasional, Jakarta, 1996)

14. Standar Nasional Indonesia, Bata Beton Pejal, Mutu dan Cara Uji SNI 03-0348-1989 (Badan Standardisasi Nasional, Jakarta,1989)

15. S.T. Yildirim, N.P. Duygun, IOP Conference Series: Mat. Sci. and Eng. 245 (2017)

16. Standar Nasional Indonesia, Bata Merah Pejal untuk Pasangan Dinding SNI 15-20942000 (Badan Standardisasi Nasional, Jakarta, 2000)

17. Green Diary, Best of 2011: Eco Friendly Homes Built with Recycled Material. Available at: https://greendiary.com/2011-eco-friendly-homes-built-recycledmaterial.html (2011)

18. C.Y. Wang, M.D. Joong, C.J. Seung, C.S. Kyu, Cem. Con. Res. 35, 4 (2005)

19. M. Frigione, Waste Man. 30, 6 (2010)

20. T. Mulyono, Concrete technology (Andi Offset, Yogyakarta, 2003)

21. K. Sobolev, M. Arikan, American Ceramic Society Bulletin 81, 1 (2002) 